\title{
Identification of the proteome complement of high royal jelly producing bees (Apis mellifera) during worker larval development*
}

\author{
Jianke $\mathrm{LI}^{\mathrm{a}}$, Huawei $\mathrm{LI}^{\mathrm{a}}{ }^{\mathrm{ab}}$, Zhaohui ZHANG ${ }^{\mathrm{c}}$, Yinghong PAN \\ ${ }^{a}$ Institute of Apicultural Research, Chinese Academy of Agricultural Science, Beijing 100093, China \\ ${ }^{b}$ Bioengineering Department, Zhengzhou University, Zhengzhou 450001, China, \\ ${ }^{c}$ Institute of Crop Science, Chinese Academy of Agricultural Sciences, The National Key Facility for Crop Gene \\ Resources and Genetic Improvement, 12 Zhongguancun Nandajie, Beijing 100081, China
}

Received 22 May 2007 - Revised 21 August 2007 - Accepted 31 August 2007

\begin{abstract}
To investigate the composition and function of the proteome during larval development of worker bees from a strain of Apis mellifera $\mathrm{L}$. artificially selected for increased royal jelly yield, proteins were partially identified by two-dimensional gel electrophoresis, mass spectrometry and protein engine identification tools that were applied to the honeybee genome. Out of 48 high abundance proteins selected for MS fingerprinting, 22 could be identified as representing annotated genes of the honey bee. These including 9 nutrient related proteins, 6 proteins associated with carbohydrate metabolism and energy production, 3 heat shock proteins, 4 other proteins related to the metabolism of amino acids, fatty acid metabolism, larval growth and cell cycle, respectively.
\end{abstract}

high royal jelly producing bee / Apis mellifera / larva / peptide mass fingerprint / proteome

\section{INTRODUCTION}

Honeybees, like many other insects, develop through complete metamorphosis from egg to larva to pupa to adult. This development occurs in the cells of the wax comb (Winston, 1979; Seeley, 1983). After the larva hatches from the egg, it grows exponentially. At the sixth day the weight of a worker bee larvae reaches $160 \mathrm{mg}, 1600$ times more than that of the first day. During the first 48 hours, worker larvae have the same developmental rate as queen larvae, while in the following 48-96 hour period, worker larvae grow faster than queen larvae (Wang, 1965; Stabe, 1930). At the early fifth instar (approximately $96 \mathrm{~h}$ of larval development), the worker larva is larger

Corresponding author: Yinghong Pan, apislijk@126.com

* Manuscript editor: Marla Spivak than the queen larva (Asencot and Lensky, 1976).

A particular feature of the honeybee is the nutrition-based mechanism of caste determination (Weaver, 1966; Beetsma, 1979; Brian, 1979). By the end of the fifth day (approximately $120 \mathrm{~h}$ of larval development), the queen larva is approximately $60 \%$ heavier than the worker larva (Wang, 1965). The queen larva has a higher metabolic rate, reflected in a higher rate of oxygen uptake starting at the mid-third instar (approximately $50 \mathrm{~h}$ of larval development) and reaching a maximum in the mid-fourth instar (72 h) (Shuel and Dixon, 1968). There are important differences in the levels of juvenile hormone between the two castes. It is known that the rate of juvenile hormone secretion by the corpora allata depends on the quality and quantity of the food ingested by the larvae (Beetsma, 1979; Wirtz and Beetsma, 1972). Juvenile hormone levels 
increase in queen larvae during the third to fifth instar, reaching a peak at early stages of the fifth instar, when they are 15 times higher than in worker larvae (Lensky et al., 1978; Rembold, 1987; Rachinsky et al., 1990).

Molecular genetic research indicates that specific genes are activated during worker and queen larvae development (Wheeler et al., 2006). An insulin-like peptide is expressed at very high levels in queen but not worker larvae during the second larval instar. Simultaneously, the gene coding for an insulin receptor is expressed at higher levels in queen larvae during the second larval instar (Evans and Wheeler, 1999). At the crucial stage of larval caste determination the ecdysone titer and transcriptional level of transcription factors involved in cell differentiation are upregulated in queen larvae, but downregulated in worker larvae (Hepperle and Hartfelder, 2001). Larvae raised as queens or workers differ greatly in their gene-expression patterns. Queens overexpress several metabolic enzymes, while workers show increased expression of a member of the cytochrome P450 family, hexameric storage proteins and a dihydrodiol dehydrogenase. Young larvae overexpress two putative heat-shock proteins (70 and $90 \mathrm{KDa}$ ), and several proteins related to RNA processing and translation (Evans and Wheeler, 2000).

Since Italian bees have been introduced into China as early as 1930s, China's scientists paid close attention to select honeybees for increasing royal jelly yield. With 50 years of effort, China has successfully bred for a high royal jelly producing bee (Apis mellifera L.), coined "jelly bee," from the introduced Italian bee. To date, this bee has become a major royal jelly producer, and has enabled China to contribute more than $90 \%$ of the global output of royal jelly, with annual production around 2000 tons (Li, 2000; Li et al., 2003; Li and Chen, 2003). As the honeybee (Apis mellifera L.) is becoming an increasingly important model organism for research on developmental biology, reverse genetics, aging (Amdam and Omholt, 2002), social behavior (Robinson et al., 2005) and neurobiology (Heisenberg, 2004), a wide range of physiological, biochemical and molecular approaches have been used to study honeybees. The recent availability of the honeybee $A$. mellifera genome and transcriptome of both the female castes provided new insights into the genetics of honeybees, as well as comparisons with other species (The Honeybee Genome Sequencing Consortium, 2006), which has stimulated new efforts in investigating the proteome profile using a proteomic approach during larval development. However, the protein-based information available for larval development research is rudimentary. Thus, the aim of the present study was to obtain a proteome complement of the worker bee larval development on a global scale.

\section{MATERIALS AND METHODS}

\subsection{Chemicals}

Immobilized $\mathrm{pH}$ gradients (IPG) strip (pH 3-10, Linear), two-dimensional gel electrophoresis (2DE) marker, Bio-lyte (pH 3-10), mineral oil were purchased from Bio-Rad Laboratories Ltd. Trisbase, ammonium persulfate (AP), sodium dodecyl sulfate (SDS), N,N,N',N'-tetramethylethylene diamine (TEMED) and glycin were from Sigma. Acrylamide, N, N'-methylenebisacrylamide, Bromophenol Blue, Coomassie Brilliant Blue (CBB) G-250, thiourea, 3-[(3-cholamidopropyl)dimethylammonio]-1-propane sulfonate (CHAPS), glycerol, bovine serum albumin (BSA) were purchased from Amresco. Agarose and urea were from Solarbio. Dithiothreitol (DTT) and iodoacetamide were from Merck. Trypsin was from Roche, trifluoroacetic acid (TFA), acetonitrile were from J. T. Baker.

\subsection{Honeybee larvae}

The line of high royal jelly producing bees (Apis mellifera L.) was from Pinghu City, Zhejiang province, China and was raised in an experimental apiary of the Bee Research Institute, Chinese Academy of Agricultural Science, Beijing, China.

Larvae of worker bees were randomly collected

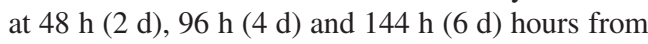
a frame from May to August 2006. To guarantee that the exact aged larvae were sampled, the queen 
was confined to a single frame for 5 hours. Subsequently, the queen was removed and the frame containing eggs was maintained in a cage made of a queen excluder, through which workers but not the queen could pass. In this manner, workers were allowed access to the developing larvae, all of which arose from eggs laid by the queen during the 5-hour confinement period. The hatched larvae were collected at 48, 96 and 144 hours by a plastic transfer tool, respectively. A total of 80 worker bees larvae were sampled from 4 colonies.

\subsection{Protein extraction}

Protein extraction was performed according to the method of Zhong et al. (2005). Previous to protein extraction, the larvae were washed three times with saline solution. The larvae (1 mg larvae/10 $\mu \mathrm{L}$ buffer) were mixed in phosphate buffer (PB) $\mathrm{pH}$ 7.6, containing $32.5 \mathrm{mmol} / \mathrm{L} \mathrm{K}_{2} \mathrm{HPO}_{4}, 2.6 \mathrm{mmol} / \mathrm{L}$ $\mathrm{KH}_{2} \mathrm{PO}_{4}, 400 \mathrm{mmol} / \mathrm{L} \mathrm{NaCl}$. The mixture was homogenized for $20 \mathrm{~min}$ on ice and sonicated for $2 \mathrm{~min}$, centrifuged at $12000 \mathrm{~g}$ and $4{ }^{\circ} \mathrm{C}$ for $10 \mathrm{~min}$, and further centrifuged at $15000 \mathrm{~g}$ and $4{ }^{\circ} \mathrm{C}$ for $10 \mathrm{~min}$. The supernatant was removed to another tube for further use. The pellets $(1 \mathrm{mg}$ larvae $/ 2 \mu \mathrm{L}$ buffer) were mixed in PB and then centrifuged at $15000 \mathrm{~g}$ and $4{ }^{\circ} \mathrm{C}$ for $10 \mathrm{~min}$. The supernatant was removed and mixed into a tube containing supernatant as a PB-soluble proteins extract, while the pellets ( $1 \mathrm{mg}$ larvae $/ 10 \mu \mathrm{L}$ buffer), containing $\mathrm{PB}$-insoluble proteins were mixed in lysis buffer (LB) $(8 \mathrm{~mol} / \mathrm{L}$ urea, $2 \mathrm{~mol} / \mathrm{L}$ thiourea, $4 \%$ CHAPS, $20 \mathrm{mmol} / \mathrm{L}$ Tris-base, $30 \mathrm{mmol} / \mathrm{L}$ DTT, $2 \%$ Biolyte $\mathrm{pH} 3-10)$. The mixture was homogenized for $10 \mathrm{~min}$ on ice and sonicated for $2 \mathrm{~min}$ and centrifuged at $15000 \mathrm{~g}$ and $4{ }^{\circ} \mathrm{C}$ for $10 \mathrm{~min}$. The supernatant was removed and added to the tube containing $\mathrm{PB}$-soluble proteins extract, and the debris was discarded. Trichloroacetic (TCA) was added to the collected supernatants to a final concentration of $10 \%$, and then the mixture was kept on ice for $10 \mathrm{~min}$ for protein precipitation and desalting. Subsequently, the mixture was centrifuged twice at $15000 \mathrm{~g}$ and $4{ }^{\circ} \mathrm{C}$ for $10 \mathrm{~min}$. The supernatant was discarded and the pellets ( $1 \mathrm{mg}$ larvae $/ 4 \mu \mathrm{L}$ buffer) were resolved in LB, then the mixture was homogenized for $5 \mathrm{~min}$ on ice and sonicated for $2 \mathrm{~min}$, and subsequently adjusted to $\mathrm{pH} 7.0$ with $2 \mathrm{~mol} / \mathrm{L}$ $\mathrm{NaOH}$. The mixture containing the protein extracts of worker bee larvae was stored at $-70{ }^{\circ} \mathrm{C}$ for further use.

\subsection{Protein determination}

Protein concentration was determined according to the method developed by Bradford (1976) using BSA as the standard. The absorption was measured at $595 \mathrm{~nm}$ (Beckman, spectrophotometer DU800).

\subsection{Two-dimensional gel electrophoresis (2-DE)}

A $500 \mu \mathrm{g}$ protein sample was suspended in LB and then mixed with rehydration buffer $(8 \mathrm{~mol} / \mathrm{L}$ urea, 2\% CHAPS, $0.001 \%$ bromophenol blue, $45 \mathrm{mmol} / \mathrm{L}$ DTT, 0.2\% Bio-lyte $\mathrm{pH} 3-10$ ). The mix-

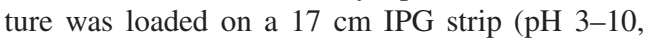
linear, Bio-Rad Hercules, CA, USA). Isoelectric focusing (IEF) was performed at $18{ }^{\circ} \mathrm{C}$ (Protean IEF Cell. Bio-Rad Hercules, CA, USA) according to the following program: $14 \mathrm{~h}$ at $50 \mathrm{~V} ; 250 \mathrm{~V}$ for $30 \mathrm{~min} \times 4$ times; $1000 \mathrm{~V}$ for $60 \mathrm{~min} ; 9000 \mathrm{~V}$ for $5 \mathrm{~h} ; 9000 \mathrm{~V}$, for $60000 \mathrm{~V} \cdot \mathrm{h}$. Before SDS-PAGE, the IPG strips were first equilibrated for $15 \mathrm{~min}$ in equilibration buffer 1 ( $6 \mathrm{M}$ urea, $0.375 \mathrm{M}$ Tris$\mathrm{HCl}$ (pH 8.8), 20\% glycerol, 2\% SDS, 2\% DTT) and then continued in equilibration buffer $2(6 \mathrm{M}$ urea, $0.375 \mathrm{M}$ Tris- $\mathrm{HCl}$ (pH 8.8), $20 \%$ glycerol, $2 \%$ SDS, $2.5 \%$ iodoacetoamide) for $15 \mathrm{~min}$. After equilibration, the strip was transferred to an SDS polyacrylamide gel, $12 \% \mathrm{~T}$ separating gel $(1.00 \mathrm{~mm})$. Meanwhile, $10 \mu \mathrm{L}$ of 2-DE marker was loaded onto a piece of filter paper, and then it was transferred adjacently to the acid tip of the strip when the filter paper was nearly dry. Second dimension electrophoresis, SDS-PAGE, was performed in a Protean II Xi Cell (Bio-Rad Hercules, CA, USA) at $25 \mathrm{~mA} / \mathrm{gel}$ for $6.5 \mathrm{~h}$. The gel was stained with CBB G250. Each sample was replicated five times and the best three runs with good reproducibility were subjected to analysis. To accurately compare spot quantities between gels that often have some variation in spot size and intensity not due to differential protein expression, normalization was done with a day 2 sample as a defined quantity of protein standard compensating for these nonexpression-related variations in spot intensity. ANOVA (Version 6.12, SAS Institute, Cary, N.C., USA), a parametric test by Duncan'method, was used to test the significance of the normalized volume in total density of identified proteins in all gels. In all statistical analysis a probability of $P<0.05$ was considered to be statistically significant. 


\subsection{Image acquisition}

Gels were scanned using a transparency mode scanner, connected to PC system, at 32-bit redgreen-blue colors and 300 dpi resolution for documentation. Images were analyzed using PDQuest V 7.3.0 (Bio-Rad Hercules, CA, USA).

\subsection{Tryptic digestion}

The CBB stained spots were excised and destained for $30 \mathrm{~min}$ using $100 \mathrm{~mL}$ acetonitrile $(50 \%)$ and $25 \mathrm{mM}\left(\mathrm{NH}_{4}\right) \mathrm{HCO}_{3} \mathrm{pH} 8(50 \%)$ for 34 times until the gel was transparent with no color, dried for $10 \mathrm{~min}$ with acetonitrile (100\%). The gels were dried for $30 \mathrm{~min}$ using a Speed-Vac system. Then $2.5 \mathrm{~mL}$ of $25 \mathrm{mM}\left(\mathrm{NH}_{4}\right) \mathrm{HCO}_{3}$ was added to the $25 \mu \mathrm{g}$ trypsin (final concentration $10 \mathrm{ng} / \mu \mathrm{L}$ ); $10 \mu \mathrm{L}$ of this solution was pipetted on each dried protein spot and incubated for $60 \mathrm{~min}$ at $4{ }^{\circ} \mathrm{C}$. The supernatant was discarded to minimize auto digestion of trypsin. Then the Eppendorf tube was turned upside down and the sample was incubated for $14 \mathrm{~h}$ at $37{ }^{\circ} \mathrm{C}$. To extract the peptide fragments from the tryptic digests, $20 \mu \mathrm{L}$ of $5 \%(\mathrm{v} / \mathrm{v})$ TFA were added and incubated for $60 \mathrm{~min}$ at $37{ }^{\circ} \mathrm{C}$. Thereafter, 20 $\mu \mathrm{L}$ of $50 \%(\mathrm{v} / \mathrm{v})$ acetonitrile [containing $2.5 \%(\mathrm{v} / \mathrm{v})$ TFA] acid were added to the gel and incubated for $60 \mathrm{~min}$ at $30{ }^{\circ} \mathrm{C}$. After each step the supernatants were pooled and dried using a Speed-Vac system.

\subsection{MALDI-TOF MS analysis and database search}

Before obtaining the mass spectra of the peptide mixture, the digested peptides were desalted and cleaned with ZipTip C18 pipette tips (Millipore Corp., BedfordMAUSA) according to the manufacturer's instructions. All analyses were performed using a Bruker Daltonics Autoflex (Bruker Daltonics Billerica, Mass. USA) operated in the delayed extraction of $190 \mathrm{~ns}$ and reflector mode with an accelerating voltage of $20 \mathrm{KV}$. The peptide mixture was analyzed using a saturated solution of $\alpha$-cyano4-hydroxycinnamic acid (CHCABruker Daltonics Billerica, Mass. USA) in 50\% acetonitrile/0.1\% trifluoroacetic acid. External calibration was performed with a peptide calibration standard (Bruker Daltonics Billerica, Mass. USA, Part No. 206195) and internal calibration with trypsin autoproteolytic fragments. Finally, the masses of proteolytic peptide fragments, were obtained by peptide mass fingerprinting (PMF), a mass spectrometry based protein identification technique. To interpret the mass spectra of protein digests, the generated peaks lists of the tryptic peptide masses were searched against MASCOT (http://www.matrixscience.com/ search_form_select.html) and Xproteo (http:// xproteo.com:2698).

\section{RESULTS}

\subsection{Protein complements of the worker larvae}

Figure 1 shows a representative 2-DE protein gel corresponding to 2, 4 and 6 d-old larvae. All the gels were analyzed with the same parameters (PDQuest 7.3.0 ) (Bio-Rad Hercules, CA, USA). The results showed that 242 (Fig. 1A), 400 (Fig. 1B) and 192 (Fig. 1C) protein spots were detected on $\mathrm{d} 2, \mathrm{~d} 4$ and d 6, respectively. Among them, 42 proteins of high abundance present in all the images (i.e. the protein was consistently resolved or expressed), and 2 and 4 spots specific to $\mathrm{d} 2$ and $\mathrm{d}$ 6 were subjected to identification, respectively.

Within the total of 22 identified proteins (Tab. I), eight were classified as nutrient proteins and one as a storage protein. Six are functionally related to the metabolism of carbohydrates and energy production, and three were identified as heat shock proteins. Also identified were an ortholog of Lethal (2) 37Cc of Drosophila, one protein related to metabolism of amino acids and related nitrogen-containing molecules, one protein identified as involved in fatty acid metabolism, and one protein was imaginal disc growth factor 4 . For the other 26 proteins we could not identify orthologs in other species..

The largest group of the identified proteins was that related to a source of nutrients for the development or growth of the larvae. These nine different forms of proteins had molecular weight (MW) values ranging from 39.98 to $113.96 \mathrm{KDa}$ and with isoelectric point $(\mathrm{pI})$ values ranging from 4.70 to 6.80 (spots 6,9 , 10, 11, 13, 17, 18, 20, 22) (Fig. 1, Tab. I), including eight major royal jelly protein isoforms (corresponding to MRJPs 2 and 3 ) and larval serum protein 2 . 


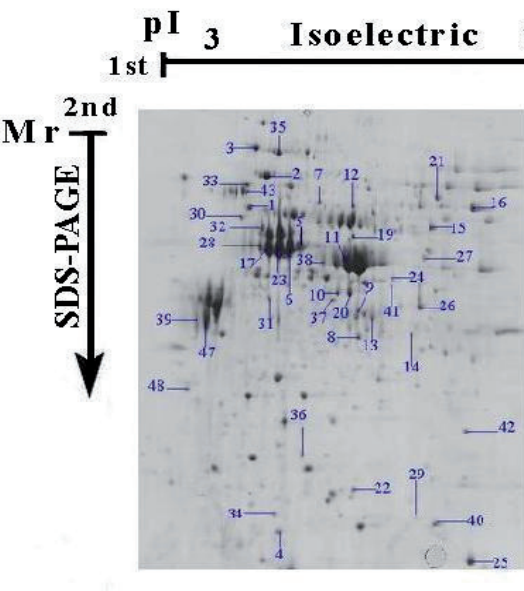

A

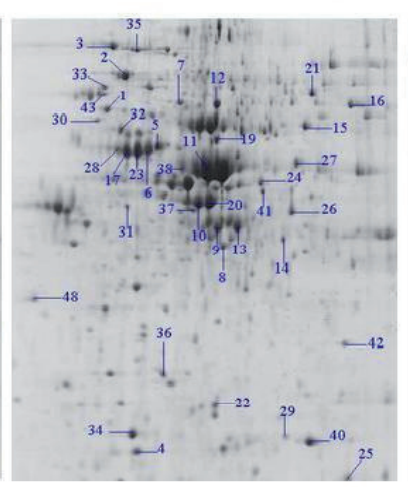

B

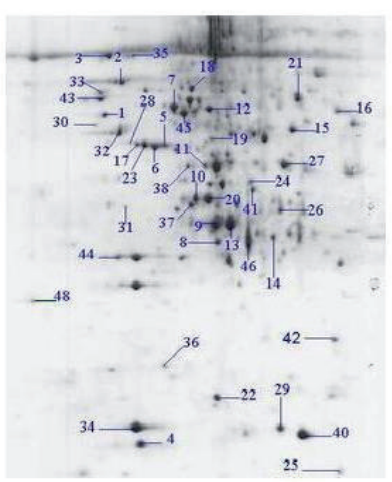

$\mathrm{C}$

Figure 1. CBB G-250 stained 2D gels of proteins of the larvae of the high royal jelly producing worker bees (Apis mellifera L.). Number-labeled spots were cut out and underwent tryptic digestion before mass spectrum analysis.

The second largest group of the identified proteins was those related to the metabolism of carbohydrates and energy production. These six different forms of proteins, with MW values ranging from 39.34 to $59.51 \mathrm{KDa}$ and $\mathrm{pI}$ values from 5.25 to 9.36 (spots $1,5,7,12$, 14, 16) (Fig. 1, Tab. I), were ATP synthase (EC 3.6.3.14), arginine kinase (EC 2.7.3.3), aldehyde dehydrogenase (EC 1.2.1.5), enolase (EC 4.2.1.11), phosphoglycerate mutase (EC 2.7.5.3) and ATP synthase alpha chain/mitochondrial precursor (EC 3.6.3.14), respectively. Among them, four spots (5, 7, $12,14)$ were identified as proteins involved in carbohydrate and energy metabolism, and two were ATPases (spots 1,16) (ATP synthase and ATP synthase alpha chain/mitochondrial precursor).

The third largest group of the identified proteins are believed to be heat shock proteins. Three different forms of heat shock proteins were identified (spots 2, 3 and 19), with MW ranging from 60.41 to $72.48 \mathrm{KDa}$ and $\mathrm{pI}$ values from 5.20 to 5.60, including a $60 \mathrm{KDa}$ heat shock protein, the mitochondrial precursor 60 KDa chaperonin (Hsp60), heat shock protein cognate 3 and heat shock protein 8 isoform 1 (Fig. 1 and Tab. I).
One protein was identified as a fatty acid binding protein (spot 4, Fig. 1, Tab. I), and a second protein was identified as an ortholog of Drosophila Lethal (2) 37Cc (spot 8, Fig. 1, Tab. I), Another one was ornithine aminotransferase (EC 2.6.1.13) related to metabolism of amino acids and related nitrogen-containing molecules (spot 15, Fig. 1, Tab. I) and the last one was imaginal disc growth factor involved in cell cycle regulation.

\subsection{Expression analysis of the identified proteins}

The normalized spot volume of the identified proteins is presented in Figure 2. Among the nutrient related proteins, five MRJP 2 were observed to be significantly higher on day 4 and day 6 than on day $2(P<0.05)$, and three MRJP 3 were all observed to be significantly higher on day $4(P<0.05)$ (Fig. 2A), while larval serum protein 2 (Lsp 2) started to be expressed beginning on day 6 (Fig. 2A).

Among the six proteins related to the metabolism of carbohydrates and energy production, arginine kinase, aldehyde dehydrogenase, enolase and phosphoglyceromutase were significantly upregulated $(P<0.05)$ during 


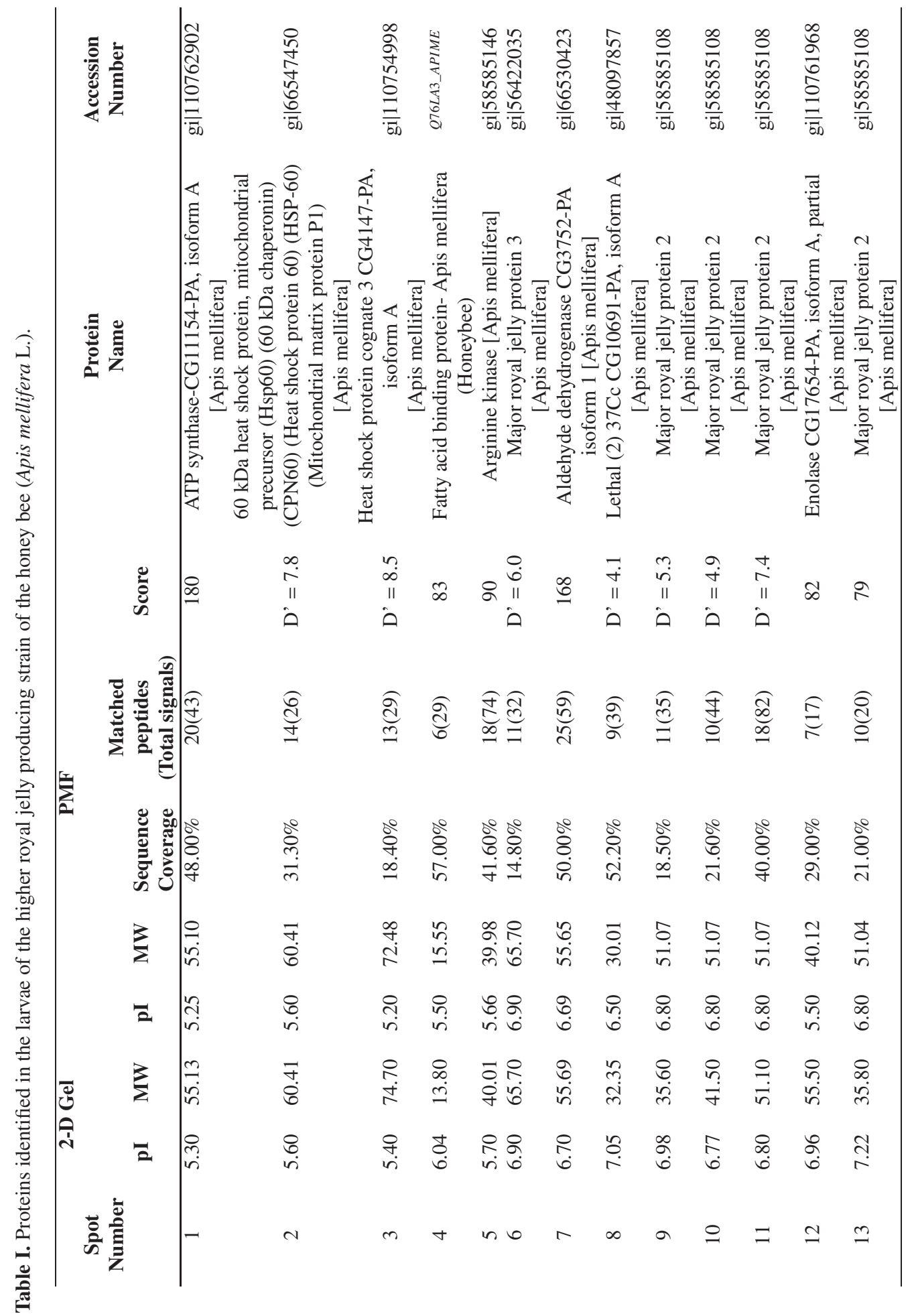




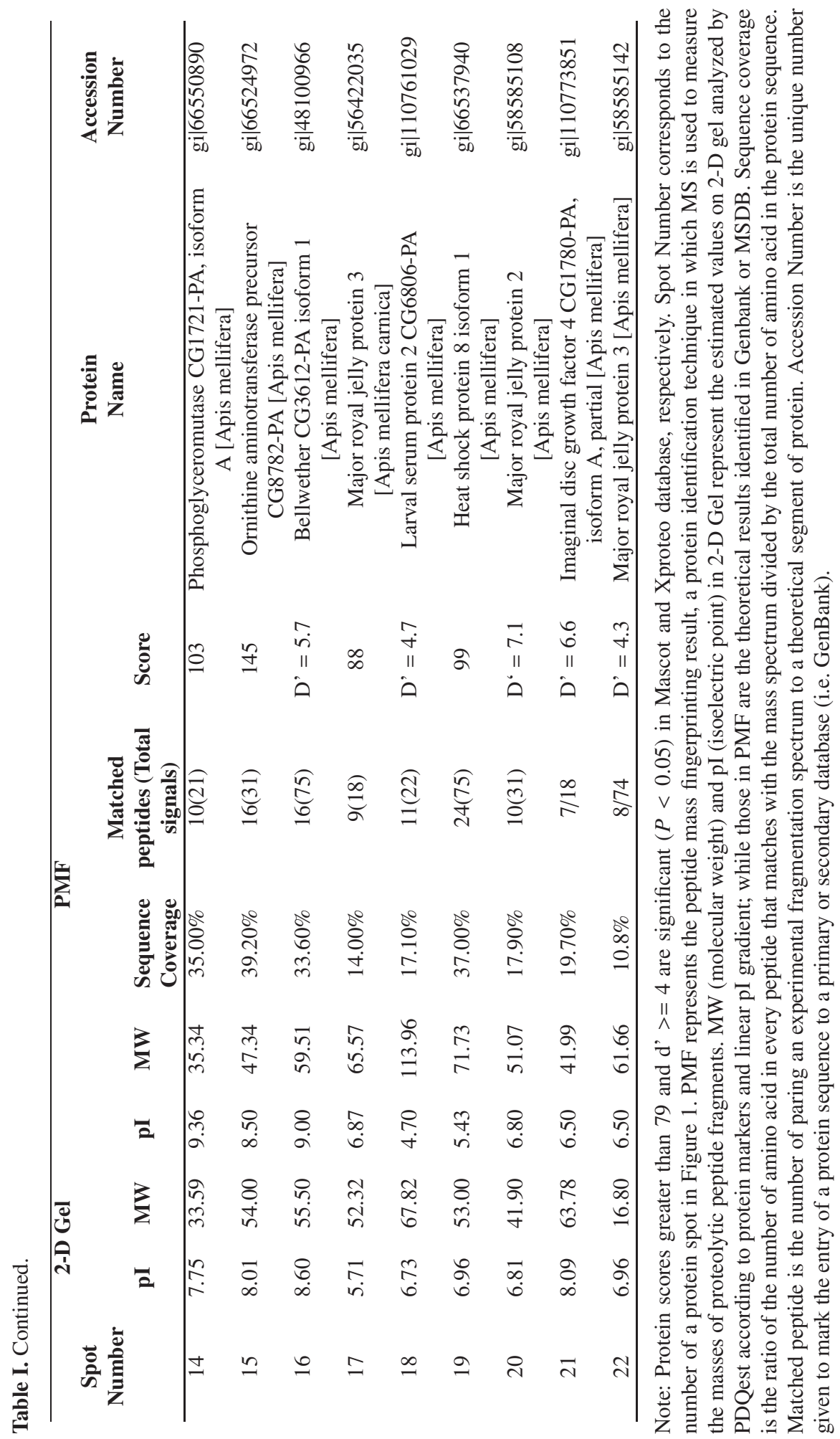



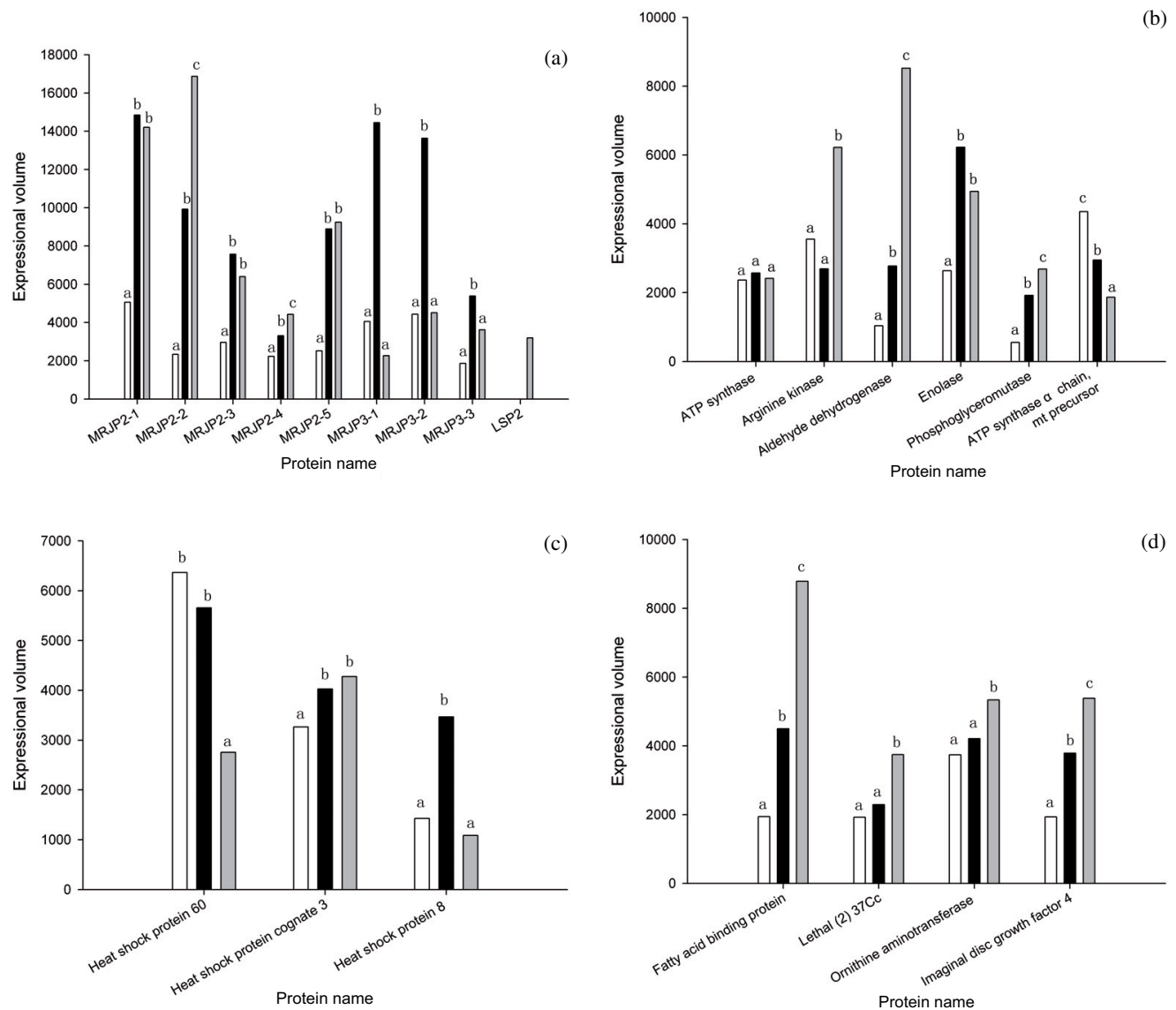

Figure 2. Expression levels of identified proteins. A, B, C and D represent 9 nutrient related proteins, 6 related to the metabolism of carbohydrates and energy production, 3 heat shock proteins and 4 other proteins, fatty acid binding protein, lethal (2) $37 \mathrm{Cc}$, Ornithine aminotransferase precursor and Imaginal disc growth factor 4 . Different lower case letters $(\mathrm{a}-\mathrm{c})$ above the bars indicate significant differences. White, black and gray bar represent the day 2, day 4 and day 6 along with the larval development.

larval development, and ATP synthase alpha chain mitochondrial precursor was significantly down-regulated $(P<0.05)$, while ATP synthase showed insignificant expression changes between days 2,4 and $6(P>0.05)$ (Fig. 2B)

Heat shock protein 60 was significantly down-regulated $(P<0.05)$, while heat shock protein cognate 3 was significantly upregulated $(P<0.05)$ and heat shock protein 8 was significantly higher on $\mathrm{d} 4$ compared to $\mathrm{d}$ 2 and d $6(P<0.05)$ (Fig. 2C).

Fatty acid binding protein and imaginal growth factor were up-regulated significantly on $\mathrm{d} 2$ and $\mathrm{d} 4$ and reached the highest level on d $6(P<0.05)$. Lethal $(2) \mathrm{Cc}$ and ornithine aminotransferase (EC 2.6.1.13) showed no expression differences between day 2 and day 4 $(P>0.05)$, but increased on day $6(P<0.05)$ (Fig. 2D).

\section{DISCUSSION}

This study attempted to explain integrative gene performance during larval development in honeybees by a global approach. Proteins were extracted from whole body samples of 
larvae, without prior removal of the intestinal tract. Since bees do not void their gut prior to the late spinning stage, some of the proteins identified in this study (e.g., the MRJPs) may actually be gut contents deriving from food (i.e. the major royal jelly proteins) that the larvae fed. It is reasonable to assume that the young larvae contain a large amount of MRJPs and, thus, these should not be included in the "larval protein complement".

The serum (storage) proteins produced by insect larvae at the end of the feeding cycle are hexameric blood proteins with one or more type of subunits (Willott et al., 1989). They show a tissue and temporal specificity of expression in the fat body of third instar larvae of Drosophila melanogaster (Jowett, 1985). In the honeybee, workers showed an increased expression of larval serum proteins during development (Evans and Wheeler, 2000). In our study we could detect this protein only on day 6 (Fig. 2A), which is consistent with insect larvae producing larval storage protein at the end of the feeding cycle (Willott et al., 1989) in order to store amino acids until they are needed during metamorphosis (Webb and Riddiford, 1988).

Six identified proteins are related to the metabolism of carbohydrates and energy production, suggesting that larval development needs much energy. Queen larvae overexpress mitochondrial protein ATP synthase (Evans and Wheeler, 2000), an enzyme that catalyzes the conversion of phosphate and adenosine diphosphate into adenosine triphosphate during oxidative phosphorylation in mitochondria (Sabbert et al., 1997; Abrahams et al., 1994). The expression of ATP synthase was invariant during larval development (Fig. 2B), suggesting that it is expressed in a constant manner and continuously supplies energy to larval growth. ATP synthase alpha chain, mitochondrial precursor, is a hydrogenexporting ATPase which produces ATP from $\mathrm{ADP}$ in the presence of a proton gradient across the membrane. The alpha chain is a regulatory subunit which belongs to the ATPase alpha/beta chain family (Kajiwara et al., 2005). Its expression was at a high level at the early stage of larval development (Fig. 2B), suggesting that they need more energy than larvae in the later stages of development. The following four enzymes, enolase, aldehyde dehydrogenase, arginine kinase, phosphoglycerate mutase (PGM), were all upregulated (Fig. 2B), indicating that larval growth needs a lot of energy. Enolase, an enzyme present in muscle tissue that acts in carbohydrate metabolism (Holt and Wold, 1961), has been found in the muscle of the forager bees (Schippers et al., 2006). Aldehyde dehydrogenase which promotes the formation of reduced coenzymes from their oxidated forms $\left(\mathrm{NAD}^{+}\right.$or $\mathrm{NADP}^{+}$) was identified in the hypopharyngeal gland of Africanized nursehoneybees (Santos et al., 2005), and is consistently overexpressed in the worker larvae (Evans and Wheeler, 2000). Arginine kinase belongs to a class of kinases that play a role in the maintenance of ATP levels by the phosphorylation of the so called "phosphagens" which then serve as a high energy source from which ATP can be rapidly replenished (Pereira et al., 2000), and is highly expressed in the compound eyes of the honey bee (Kucharski et al., 1998). A gene encoding PGM was cloned from the venom gland of Apis cer$a n a$, which catalyzes the internal transfer of a phosphate group from C-3 to C-2, which results in the conversion of 3-phosphoglycerate (3PG) to 2-phosphoglycerate (2PG) (Chander and Lamani, 1999).

Heat shock proteins (Hsps), which are highly conserved and are the most abundant intracellular proteins, are a group of proteins that are present in all cells in all life forms (Lindquist and Craig, 1988). They are induced when a cell undergoes various types of environmental stress like heat, cold and oxygen deprivation. Hsps are also present in cells under perfectly normal conditions. They act as 'chaperones,' making sure that the cell's proteins are correctly folded and in the right place at the right time. They also shuttle proteins from one compartment to another inside the cell, and transport old proteins to 'garbage disposals' inside the cell (Hirsch et al., 2006; Folch-Mallol et al., 2004; Binder, 2006). Heat shock protein 60 (Hsp60) is a mitochondrial chaperonin that is typically held responsible for the transport and refolding of proteins from the cytoplasm into the mitochondrial matrix 
(Cheng et al., 1990; Johnson et al., 2003). For the honeybee, there is no report on this protein at the present although it is essential from the early stages of embryogenesis of Drosophila melanogaster (Kozlova et al., 1997).

The heat shock proteins 70 (Hsp70s) are a family of ubiquitously expressed proteins. Proteins with similar structure exist in virtually all living organisms. Members of the Hsp70s family are also involved in appropriate folding and trafficking of newly synthesized proteins in the cell. Hsc70, which is expressed constitutively, and Hsp70, the expression of which is stress- and heat shockinduced, are often considered to have similar cellular functions in this regard, but there are suggestions that the intracellular functions of these homologous but not identical proteins may differ (Goldfarb et al., 2006). The presently identified heat shock protein 8 isoform 1 , or heat shock $70 \mathrm{kDa}$ protein 8 (Hspa8) and the heat shock $70 \mathrm{KDa}$ protein cognate 3 (Hsc70-3), are both Hsc70, which are constitutively expressed and perform several functions (Goldfarb et al., 2006). Hsc70-3 probably plays a role in facilitating the assembly of multimeric protein complexes inside the endoplasmic reticulum (ER) of Drosophila melanogaster (Miara et al., 2002). A Hspa8 gene has been annotated in the honeybee genome (The Honeybee Genome Sequencing Consortium, 2006). Three putative genes coding for Hsp 20, Hsp 83 and Hsp 70 have been reported in the head of the worker bees (Kucharski and Maleszka, 2002). The young worker larvae overexpress two putative heatshock proteins (70 and $90 \mathrm{KDa}$ ) (Evans and Wheeler, 2000). The continued presence of Hsps in the larval proteome complement can probably best be explained by their general function in protein folding.

Fatty acid binding proteins (FABPs) are abundant low-molecular-weight cytosolic proteins in tissues involved in fatty acid (FA) metabolism (Kaikaus et al., 1990). FABPs are upregulated during the six days of larval development (Fig. 2D), which is consistent with the previously observed overexpression of FABPs in worker larvae (Evans and Wheeler, 2000). Lethal protein belongs to the prohibitin family required for larval metabolism or for the pro- gression of the larva into a pupa. It is expressed in early embryos, late embryos, late third instar larvae and adults of Drosophila melanogaster (Black et al., 1987; McCrady and Tolin, 1994; Wright, 1996). For the honeybee, this protein has been annotated in a brain EST library of adult workers (Whitfield et al., 2002), and it has since been reported to be expressed in adult bees (Kucharski and Maleszka, 2002). Ornithine aminotransferase precursor is expressed at high levels in the fat body of third instar larvae in both Drosophila ananassae and Drosophila melanogaster, where it is related to the metabolism of amino acids and related nitrogen-containing molecules (Yoshida et al., 1997). The three proteins mentioned above are upregulated during worker larval development (Fig. 2D), indicating an increasing metabolic rate along with the progression from larvae to a pupa.

\section{CONCLUSION}

Although individual genes, proteins and metabolic enzymes have been extensively studied, the protein composition of larvae during development, studied by a global proteomic approach is still in its infancy. The availability of multiple high-quality genome sequences, including the honeybee genome, provides an opportunity to systemically explore the proteins involved in developmental processes.

Among 48 selected high abundance proteins from the protein complement of honey bee worker larvae, 22 were identified. Larval serum protein 2 expressed on day 6 functions to store accumulated amino acids until they are used during metamorphosis. Four proteins, enolase, arginine kinase, aldehyde dehydrogenase and phosphoglyceromutase, directly involved in carbohydrates and energetic metabolisms showed an up-regulated trend. ATP synthetase was invariable, while ATP synthase alpha chain, mitochondrial precursor, had a significantly down-regulated trend, suggesting that developmental progression requires much energy. The continued presence of Hsps, $(60 \mathrm{KDa}$ heat shock protein mitochondrial precursor, heat shock protein 
cognate 3 and heat shock protein 8 isoform 1) in the larval proteome complement can probably best be explained by their general function in protein folding. Lethal (2) $37 \mathrm{Cc}$, a protein involved in DNA repair and cell cyle progression, is probably required for larval metabolism or for the progression of the larva into a pupa, ornithine aminotransferase precursor, related to metabolism of amino acids and nitrogen-containing molecules, and fatty acid binding protein involved in fatty acid metabolism, all showed an up-regulated trend with larval age.

These preliminary results indicate that larval development is a dynamic and integrated process requiring a variety of protein functions. Because these results present only some of the proteins involved in larval development, more work needs to be done to obtain a whole functional profile of proteins.

\section{ACKNOWLEDGEMENTS}

This work is supported by the project of research and demonstration of bee-products security and application (2006BAD06B04), and integration and demonstration of balanced feed for ruminant and aquatic animals (2006BAD12B08-06), key projects of the national scientific supporting plan of the 11th Five-Year Development (2006-10), basic scientific research found of Chinese academy of agricultural science (JBKY0032007016CAAS) and special scientific and research fund for public welfare industry (nyhyzx07-041).

Analyse du protéome, lors du développement larvaire, des ouvrières d'une lignée d'abeilles (Apis mellifera) produisant de grandes quantités de gelée royale.

Apis mellifera / larve / protéome / peptide mass fingerprinting / lignée productrice de gelée royale

\footnotetext{
Zusammenfassung - Analyse des Proteoms der Larvalentwicklung von Arbeiterinnen einer Zuchtlinien der Honigbiene (Apis mellifera), die in hohen Mengen Gelée Royale produziert. Mit der Verfügbarkeit des komplett sequenzierten und annotierten Genoms der Honigbiene liegen jetzt Proteomanalysen im Rahmen der Möglichkeit. Obwohl einzelne Gene, Proteine und Enzyme des
}

Metabolismus bereits seit einiger Zeit intensiv untersucht werden, stecken generelle Proteomanalysen, z.B. zum Proteom der Larvalentwicklung, noch in den Kinderschuhen. Ziel dieser Studie war eine systematische Untersuchung der Proteine, die in diesem Entwicklungsprozess eine Rolle spielen. Der experimentelle Ansatz bestand in einer zweidimensionalen elektrophoretischen Auftrennung gefolgt von MALDI-TOF Analysen der einzelnen Proteinspots.

Aus der Gesamtzahl der Proteine, die in der Larvalentwicklung zu finden waren, identifizierten wir 22 Spots (Abb. 1; Tab. I). Diese umfassten 9 Nahrungsproteine, 6 Proteine mit Bezug zum Kohlenhydratstoffwechsel und zur Energieproduktion, 3 Hitzeschockproteine, sowie 4 weitere Proteine mit Bezug zum Aminosäurenstoffwechsel, Fettsäurenstoffwechsel, Zellzyklus und zur Larvalentwicklung allgemein. Einige der hier identifizierten Proteine (z.B. die Gelée Royal Proteine) stammen vermutlich aus dem Darm und stellen so einen Teil der Larvennahrung dar, aber nicht des larvalen Proteoms im eigentlichen Sinne.

Das Larvale Serumprotein 2 findet sich vor allem an Tag 6 der Entwicklung stark angereichert und könnte eine Rolle in der Speicherung von Aminosäuren für die Metamorphose spielen (Abb. 1 und 2). Vier der im Kohlenhydratstoffwechsel und der Energieproduktion wichtigen Proteine, Enolase, Argininkinase, Aldehyddehydrogenase und Phosphoglyzeromutase zeigten eine ansteigende Expression in der Entwicklung (Abb. 1 und 2). ATPSynthase zeigte ein unverändertes Expressionsmuster, während der Vorläufer einer alpha-Kette der mitochondrialen ATP-Synthase zunehmend weniger exprimiert wird. Diese Befunden deuten darauf hin, dass die Entwicklung energieabhängig ist. Die Persistenz von Hitzeschockproteinen im larvalen Proteom (des mitochondrialen Vorläufers eines $60 \mathrm{kDa}$ Hsp, des Hitzeschock-ähnlichen Proteins 3 und der Isoform 1 des Hitzeschockproteins 8) kann mit ihrer Rolle in der Proteinfaltung erklärt werden (Abb. 1 und 2). Das Protein Lethal (2) 37Cc spielt in der DNA-Reparatur und im Zellzyklus eine Rolle und ist hier vermutlich für den larvalen Stoffwechsel und den Übergang zur Puppenphase von Bedeutung. Der mit dem Aminosäuren- und Nitratstoffwechsel in Verbindung stehende Vorläufer des Enzyms OrnithinAminotransferase und das im Fettstofwechsel wichtige Fettsäuren-Bindungsprotein zeigten beide einen Anstieg der Expression im Verlauf der Larvalentwicklung (Abb. 1 und 2).

Diese Ergebnisse zeigen einerseits, dass die Larvalentwicklung ein dynamischer Prozess ist, der eine Vielzahl an Proteinen mit unterschiedlichen Funktionen erfordert. Andererseits sind dies jedoch nur vorläufig Ergebnisse, da nur ein kleiner Teil der Proteinspots tatsächlich identifiziert werden konnte, und somit weitere Untersuchungen erforderlich sind. 
Gelée Royale produzierende Biene / Apis mellifera / Larve / Peptidmasse-Fingerprinting / Proteom

\section{REFERENCES}

Abrahams J.P., Leslie A.G., Lutter R., Walker J.E. (1994) Structure at 2.8 A resolution of F1-ATPase from bovine heart mitochondria, Nature 370, 621628.

Amdam G.V., Omholt S.W. (2002) The regulatory anatomy of honeybee lifespan, J. Theor. Biol. 216, 209-228.

Asencot M., Lensky Y. (1976) The effect of sugar and juvenile hormone on the differentiation of the female honeybee larvae (Apis mellifera L.) to queens, Life Sci.18, 693-700.

Beetsma J. (1979) The process of queen-worker differentiation in the honeybee, Bee World 60, 24-39.

Binder R.J. (2006) Heat shock protein vaccines: from bench to bedside, Int. Rev. Immunol. 25, 353-375.

Black B.C., Pentz E.S., Wright T.R. (1987) The alpha methyl dopa hypersensitive gene 1(2)amd, and two adjacent genes in Drosophila melanogaster: physical location and direct effects of amd on catecholamine metabolism, Mol. Gen. Genet. 209, 306-312.

Bradford M.M. (1976) A rapid and sensitive method for the quantification of microgram quantities of protein utilizing the principle of protein dye binding, Anal. Biochem. 72, 248-254.

Brian M.V. (1979) Caste differentiation and division of labor, in: Hermann H.R. (Ed.), Social Insects, New York, London, Academic Press, pp. 121-221.

Chander M., Lamani M. (1999) Structural studies on a 2,3-diphosphogly-cerate independent phosphoglycerate mutase from Bacillys stearothermophilus. J. Struct. Biol. 126, 156-165.

Cheng M.Y., Hartl F.U., Horwich A.L. (1990) The mitochondrial chaperonin HSP60 is required for its own assembly, Nature 348, 455-458.

Evans J., Wheeler D. (1999) Differential gene expression between developing queens and workers in the honey bee, Apis mellifera, Proc. Natl. Acad. Sci. USA 96, 5575-5580.

Evans J., Wheeler D. (2000) Expression profiles during honeybee caste determination, Genome Biol. 2, 16.

Folch-Mallol J.L., Garay-Arroyo A., Lledias F., Covarrubias R.A.A. (2004) The stress response in the yeast Saccharomyces cerevisiae, Rev. Latinoam Microbiol. 46, 24-46.

Goldfarb S., Kashlan O., Watkins J., Suaud L., Yan W., Kleyman T., Rubenstein R. (2006) Differential effects of Hsc70 and Hsp70 on the intracellular trafficking and functional expression of epithelial sodium channels, Proc. Natl. Acad. Sci. USA 103, 5817-22.

Heisenberg M. (2004) Mushroombody memoir: from maps to models, Nature 4, 266-275.

Hepperle C., Hartfelder K. (2001) Differentially expressed regulatory genes in honey bee caste development, Naturwissenschaften 88, 113-116.

Hirsch C., Gauss R., Sommer T. (2006) Coping with stress: cellular relaxation techniques, Trends Cell Biol. 16, 657-663.

Holt A., Wold F. (1961) The isolation and characterization of rabbit muscle enolase, J. Biol. Chem. 236, 3227-3231.

Johnson R.B., Fearon K., Mason T., Jindal S. (2003) Cloning and characterization of the yeast chaperonin Hsp60 gene, Gene 84, 295-302.

Jowett T. (1985) The regulatory domain of a larval serum protein gene in Drosophila melanogaster, J. Exp. Mar. Biol. Ecol. 4, 3789-3795.

Kaikaus R.M., Bass N.M., Ockner R.K. (1990) Functions of fatty acid-binding proteins, Experientia 46, 617-630.

Kajiwara H., Ito Y., Imamaki A., Nakamura M., Mita K., Ishizaka M. (2005) Protein profile of silkworm midgut of fifth-instar day-3 larvae, J. Electrophoresis 49, 61-69.

Kozlova T., Perezgasga L., Reynaud E., Zurita M. (1997) The Drosophila melanogaster homologue of the hsp60 gene is encoded by the essential locus $\mathrm{L}(1) 10 \mathrm{Ac}$ and is differentially expressed during fly development, Dev. Genes Evol. 207 253-263.

Kucharski R., Maleszka R. (1998) Arginine kinase is highly expressed in the compound eye of the honey bee, Apis mellifera, Gene 211, 343-349.

Kucharski R., Maleszka R. (2002) Evaluation of differential gene expression during behavioral development in the honeybee using microarrays and northern blots, Genome Biol. [online] http://genomebiology.com/2002/3/2/research/0007 (accessed on 5 November 2007).

Kucharski R., Maleszka R., Hayward D.C., Ball E.E. (1998) A royal jelly protein is expressed in a subset of Kenyon cells in the mushroom bodies of the honey bee brain, Naturwissenschaften 85, 343 346.

Lensky Y., Baehr J.C., Porcheron P. (1978) Dosages radioimmunologiques des ecdysones et des hormones juvéniles au cours du développement post embryonnaire chez les ouvrières et les reines d'abeille (Apis mellifera L. var ligustica), C.R. Acad. Sci. Paris 287, 821-824.

Li J.K. (2000) Technology for royal jelly production, Am. Bee J. 140, 469-472.

Li J.K., Chen S.L. (2003) Royal jelly and human health, Am. Bee J. 143, 398-402.

Li J.K., Chen S.L., Zhong B.X., Su S.K. (2003) Optimizing royal jelly production, Am. Bee J. 143, 221-223. 
Lindquist S., Craig E.A. (1988) The heat-shock proteins, Annu. Rev. Genet. 22, 631-677.

McCrady E., Tolin D.J. (1994) Effects of Ddc cluster lethal alleles on ovary growth, attachment, and egg production in Drosophila, J. Exp. Zool. 268, 469476.

Miara S., Crosby M.A., Mungall C.J., Matthews B.B. (2002) Annotation of the Drosophila melanogaster euchromatic genome: a systematic review, Genome Biol. 3, 22.

Pereira F.A., Tsai M.J., Tsai S.Y. (2000) COUP-TF orphan nuclear receptors in development and differentiation, Cell Mol. Life Sci. 57, 1388-1398.

Rachinsky A., Strambi C., Strambi A. Hartfelder K. (1990) Caste and metamorphosis: Hemolymph titers of juvenile hormone and ecdysone in last instar honeybee larvae, Gen. Comp. Endocr. 79, 3138.

Rembold H. (1987) Caste specific modulation of juvenile hormone titers in Apis mellifera, Insect Biochem. 17, 1003-1006.

Robinson G.E., Grozinger C.M., Whitfield C.W. (2005) Sociogenomics: social life in molecular terms, Nat. Rev. Genet. 6, 257-271.

Sabbert D., Engelbrecht S., Junge W. (1997) Functional and idling rotatory motion within F-1-ATPase, Proc. Natl. Acad. Sci. USA 94, 4401-4405.

Santos K.S., Santos L.D., Mendes M.A., Souza B.M., Malaspina O., Palma M.S. (2005) Profiling the proteome complement of the secretion from hypopharyngeal gland of Africanized nursehoneybees (Apis mellifera L.), Insect Mol. Biol. 35, 85-91.

Schippers M.P., Dukas R., Smith R.W., Wang J., Smolen K., McClelland G.B. (2006) Lifetime performance in foraging honeybees: behaviour and physiology, J. Exp. Biol. 209, 3828-3836.

Seeley T.D. (1983) The ecology of the temperate and tropical honey bee societies, Am. Sci. 71, 264272.

Shuel R.W., Dixon S.E. (1968) Respiration in developing honeybee larvae, J. Apic. Res. 7, 11-19.

Stabe H.A. (1930) The rate of growth of worker, drone and queen larvae of the honeybee, Apis mellifera, J. Econ. Entomol. 23, 447-453.
The Honeybee Genome Sequencing Consortium (2006) Insights into social insects from the genome of the honeybee, Apis mellifera, Nature 443, 931-949.

Wang D.I. (1965) Growth rates of young queen and worker honeybee larvae, J. Apic. Res. 4, 3-5.

Weaver N. (1966) Physiology of caste determination, Annu. Rev. Entomol. 11, 79-102.

Webb B., Riddiford L. (1988) Synthesis of two storage proteins during larval development of the tobacco hornworm, Manduca Sexta, Dev. Biol. 130, 671681.

Wheeler D.E., Buck N., Evans J.D. (2006) Expression of insulin pathway genes during the period of caste determination in the honey bee, Apis mellifera, Insect Mol. Biol. 15, 597-602.

Whitfield C.W., Band M.R., Bonaldo M.F., Kumar C.G., Liu L., Pardinas J.R., Robertson H.M., Soares M.B., Robinson G.E. (2002) Annotated expressed sequence tags and cDNA microarrays for studies of brain and behavior in the honey bee, Genome Res.12, 555-566.

Willott E., Wang X.Y., Wells M.A. (1989) cDNA and gene sequence of Manduca sexta arylphorin, an aromatic amino acid-rich larval serum protein, J. Biol. Chem. 264, 19052-19059.

Winston T.D. (1979) Intra-colony demography and reproductive rate of the Africanized honeybee in South America, Behav. Ecol. Sociobiol. 12, 7892.

Wirtz P., Beetsma J. (1972). Induction of caste differentiation in the honey bee (Apis mellifera) by juvenile hormone, Entomol. Exp. Appl. 15, 517-520.

Wright T.R.F. (1996) Phenotypic analysis of the Dopa decarboxylase gene cluster mutants in Drosophila melanogaster, J. Hered. 87, 175-190.

Yoshida K.M., Juni N., Hori S.H. (1997) Molecular cloning and characterization of Drosophila ornithine aminotransferase gene, Genes Genet. Syst. 72, 9-17.

Zhong B.X., Li J.K., Lin J.R., Liang J.S., Su S.K., Xu H.S., Yan H.Y., Zhang P.B., Fu J.H. (2005) Possible effect of $30 \mathrm{~K}$ proteins in embryonic development of silkworm Bombyx mori, Acta Biochem. Biophys. Sin 37, 355-361. 